\title{
Corporate Determinants and Human Resource Accounting Disclosure of Listed Banks in Nigeria
}

\author{
Ayodeji M. ADEJUWON \\ Department of Accounting, Adekunle Ajasin University, Akungba Akoko, Ondo State, \\ Nigeria \\ E-mail: ayoadeju2@gmail.com \\ Felix OLURANKINSE (PhD) \\ Department of Accounting, Adekunle Ajasin University, Akungba Akoko, Ondo State, \\ Nigeria \\ E-mail: olurankinsefelix@yahoo.com \\ Olugbenga JINADU (PhD) (Corresponding Author) \\ Department of Accountancy, Rufus Giwa Polytechnic, Owo, Ondo State, Nigeria \\ E-mail: jinaduolugbenga@gmail.com
}

Received: Oct. 25, 2020 Accepted: Nov. 17, 2020 Online published: Nov. 24, 2020

doi:10.5296/ijhrs.v10i4.17873 URL: https://doi.org/10.5296/ijhrs.v10i4.17873

\begin{abstract}
The study investigates whether a significant relationship exists between corporate determinants and human resource accounting disclosure of selected banks in Nigeria. It also looks at whether human resource accounting disclosure is influenced by banks profitability, firm size and listing age. Data were obtained from the annual reports and corporate websites of the selected banks for the periods between 2014 and 2018. In testing the research hypotheses, the study engaged the use of panel least square regression in analysing the data. The findings revealed that there is a significant positive relationship between profitability, firm size and human resource accounting disclosure. However, listing age exhibited no relationship with human resource accounting disclosure. The study recommends that listed banks in Nigeria should be encouraged to mandatorily disclose human resource accounting information so as to enhance their social reputation and reduce the potential agency costs.
\end{abstract}


Also, the study contributes to the existing models, in terms of depicting specific attributes that measure the determinants of human resource accounting disclosure of listed banks in Nigeria.

Keywords: human resource accounting disclosure, firm size, listing age, profitability

\section{Introduction}

Employees are one of the most relevant components of any organization. The soul of any organisation is not physical assets but the organ that propels them. The personnel who handle the physical assets of the organisation keep the organisation alive. There is no difference of opinion about the fact that people are the relevant components of an entity. Sarkar, Alam and Ali (2016) observed that every aspect of a firm's activities is determined by the competence, motivation and general effectiveness of its human organizations. Consequently, the public concern for the association between corporate organisations and the employees has culminated to the sudden appearance of human resource accounting disclosure (Khadijeh, 2015).

The emergence of human resource accounting in the 1960s has provided researchers with an opportunity to find out the benefits derivable by organisations from their connection with the employees (Athanasios, Antonios \& Despina, 2013). Human resource accounting, according to Sarkar et al., (2016), is the process of establishing and estimating data about human resource and communicating this information to interested parties. Human resource accounting disclosure is an important process used by companies to communicate information about employees who possess knowledge and skills that give future advantages to the organization and is affected by a diversity of factors such as profitability, firm size and listing age (Ullah \& Karim, 2015). These factors have been argued by researchers as having a role in determining human resource accounting disclosure (Sarkar et al., 2016).

Consequent upon the decision to disclose information about human resource, companies globally have started seeking ways of motivating their employees through the communication of qualitative information about their activities (Akbas, 2014). This has, therefore, increased studies on human resource accounting disclosures by corporate organisations (Sarkar et al., 2016). Nevertheless, differences in human resource accounting disclosures have been looked at in relation to company's characteristics like industry type, global reporting initiatives, listing status in Nigeria (John, 2016; Ojokuku \& Oladejo, 2017). Although, there is lack of studies on the attributes of human resource accounting disclosures in Nigeria in terms of profitability, firm size and listing age. Therefore, the need to understand the agents affecting human resource accounting disclosure is required purposely to improve accountability and particularly for comprehensive disclosure by individual organisations.

Corporate human resource accounting disclosures may, therefore, be looked at as a means of legitimising companies to their stakeholders, as companies try to convince the general public that they consider stakeholders' interests and share mutual purposes (Mathews, 2004; Deegan, 2007). In literature, a detailed view of human resource accounting disclosures has been taken, with some authorities (Abhayawansa, 2008; Ullah \& Karim, 2015; Sarkar, Alam \& Ali, 2016) 
interpreting human resource accounting disclosures as corporate attempts to legitimise business activities. Despite this, the disclosure of human resource accounting emerged as part of corporate obligation on a voluntary basis for companies to demonstrate their accountability to employees and stakeholders (Ullah \& Karim, 2015). As a result, the desire for human resource accounting disclosure is on the increase (Athanasios et al., 2013).

In response to this desire, companies have reacted with a significant increase in voluntary disclosures through their corporate publication channels, such as annual reports (Unerman, 2000), and/or other communication media like corporate web pages, company brochure and press releases on human resource issues (Adnan, Staden \& Hay, 2010). As a result, there is dramatic increase in corporate human resource disclosure (Cormier, Ledoux \& Magnan, 2011). However, this varies widely from company to company in line with period of time (Campbell, Craven \& Shrives, 2003).

To this end, many developed countries like Australia, Canada, and the United States of America have been greatly concerned with the factors that determine human resource accounting disclosure (Athanasios et al., 2013). However, in spite of Nigeria being one of the countries that is sensitive to human resource development, coupled with the increasing level of stakeholders' agitation for human capital development, not much has been done in the area of corporate determinants of human resource accounting disclosure. In addition, the accounting systems as well as regulatory bodies have failed to address human resource issues (Oyewo, 2013). Also, there is hardly any pronouncement from the accounting standard body on the issue of human resource disclosure, as the professional accounting bodies in the developing countries (like Nigeria) are yet to give human resource accounting information the attention it deserves (Adeyemi \& Ayanlola, 2015). The accounting systems have also failed to address the various needs of various stakeholders.

Moreover, most empirical studies carried out in the developed and developing economies, including Nigeria (Athanasios et al., 2013; Sarkar et al., 2016; John, 2016; Ojokuku \& Oladejo, 2017) have produced inconsistent and mixed results. Hence, the results of most studies conducted are either reporting positive or sometimes negative results. Also, methodological weaknesses exist in terms of one medium of reporting (i.e. annual report) and short period of observation in most prior studies (Oyewo, 2013; Ullah \& Karim, 2015).

In spite of the increase in human resource disclosure, corporate organisations' desire to satisfy diverse stakeholders in respect of information is low (Athanasios et al., 2013; Ojokuku \& Oladejo, 2017). Managers of corporate organisations always consider their own interests in the discharge of their duties. Hence, there is lack of evidence in Nigeria to explain the interaction between corporate determinants and their disclosure behaviour. Thus, a gap exists due to prior studies that have not comprehensively addressed these topical issues. In the light of the above, this study basically examines the relationship between corporate determinants and human resource accounting disclosure of the banking industry in Nigeria. 


\section{Literature Review and Hypothesis Development}

\subsection{Determinants of Human Resource Accounting Disclosure}

Human resource accounting disclosure and the extent of corporate determinants in Nigeria have raised doubts about the existence of human resource accounting activities in Nigeria (Ojokuku \& Oladejo, 2017). Hence, a claim that the focus should now be more on improving the human resource accounting disclosure, particularly to boost shareholder's insight and influence corporate behaviour in organization (John, 2016; Ojokuku \& Oladejo, 2017). Therefore, human resource accounting information disclosure has the ability to increase shareholder's wealth and can be considered as one of the essential parts of good corporate reporting (Athanasios et al., 2013).

Consequently, human resource accounting disclosure needs to be converged to improve disclosure quality. This situation has been linked with the recognition that good human resource accounting disclosure demands consideration of the impact an organisation has on the employees (Oba \& Fodio, 2012). This has led to a considerable debate in recent times the desire for strong human resource accounting disclosure with countries globally drawing up guidelines and modality to strengthen corporate disclosure systems (Ullah \& Karim, 2015).

The definition human resource accounting has been discussed in previous studies (Ullah \& Karim, 2015; Sarkar et al., 2016). The Report of the Committee on Human Resource Accounting (American Accounting Association, 1973) defines this as "the process of establishing and estimating data about human resources and communicating same to the interested parties". Flamholtz (1973) defines it as "accounting for people as organisation resources". Therefore, human resource accounting is seen to influence the quality of accounting information (Khadijeh, 2015) that has a significant impact on investors' confidence (Deegan, 2007).

Human resource accounting disclosure, therefore, is the communication and demonstration of a company's commitment to enhancing human resource performance to its stakeholders (Oba $\&$ Fodio, 2012). As a result, corporate determinants such as profitability, firm size and listing age have been seen to impact positively on the human resource accounting (Athanasios et al., 2013; Ullah \&Karim, 2015). In this study, therefore, the corporate determinant variables to be examined are profitability, firm size and listing age.

\subsection{Theoretical Framework}

This study is hinged on stakeholder theory as a basic motive to minimise the disclosure gap by meeting stakeholders' expectations concerning human resource accounting disclosure. In addition, the theory has been generally employed in accounting literature as providing strong justification for the factors affecting human resource accounting disclosure (Athanasios et al., 2013; Sarkar et al., 2016). This is due to the fact that stakeholders are powerful over company's resources and they are interested in human resource behaviour of companies (Athanasios et al., 2013). Furthermore, stakeholder theory provides means of dealing with multiple stakeholders with multiple conflicting interests. Managing these conflicts necessitates the utilisation of voluntary disclosure, particularly human resource accounting 
disclosure by managers to communicate with stakeholders (Micah, Ofurum \& Ihendinihu, 2012).

Conclusively, stakeholder theory regards human resource accounting disclosure as a means by which stakeholders are motivated to support the continued existence of the organisation (Evangelinos \& Skouloudis, 2014). However, Ullah and Karim (2015) concluded that legitimacy theory was inadequate to fully explain corporate human resource accounting disclosure as it provides limited human resource information. Similarly, agency theory is seen as a cause of information gap (Enofe, Mgbame, Otuya \& Ovia, 2013) as managers could conceal negative human resource accounting information (Athanasios et al., 2013). Hence, stakeholder theory is adopted as it provides a useful framework to evaluate the determinants of human resource accounting disclosure among quoted banks in Nigeria.

\subsection{Review of Prior Studies}

In this subsection, the numbers of studies that have been advanced on corporate determinants and human resource accounting disclosure are discussed.

\subsubsection{Profitability and Human Resource Accounting Disclosure}

Within the context of human resource accounting disclosure, the central issue often discussed is whether profitability can be a significant factor in determining human resource accounting disclosure. Profitability is the ability to make profit from all the business activities. It shows how effective management is to make profit using resources available. According to Harward and Upton (2012), profitability is the ability to use a given investment to earn a return.

In literature, a study argues that profitability improved human resource accounting disclosure. Currently, no verifiable evidence exists on the relationship between profitability and human resource accounting disclosure in Nigeria. Though, a significant positive relationship between profitability and human resource accounting disclosure has been consistently found by prior studies such as Syed (2009), Ahangar (2011), Rehman, Rehuman and Zaliad (2011), Micah et al., (2012), Akintoye (2012), Enofe et al., (2013) and Aggarwal and Verma (2020). However, Athanasios et al., (2013), Ullah and Karim (2015) and Sarkar et al., (2016) found an insignificant association between profitability and human resource accounting disclosure using regression analysis. Given the impact of profitability on human resource accounting disclosure, the following hypothesis is tested:

$\mathrm{H}_{1}$ : There is no significant relationship between profitability and the extent of human resource accounting disclosure of the banking industry in Nigeria.

\subsubsection{Firm Size and Human Resource Accounting Disclosure}

Limited studies have been undertaken to investigate the relationship between the firm size and human resource accounting disclosure. Firm size can be viewed in terms of assets owned by the organisation because opportunities abound to the firm as a result of the assets acquired which are also related to production efficiency (Hossain, 2012). Particularly, a number of studies over the past decades test the influence of firm size on the level of disclosure. Most authorities demonstrated a positive association between company size and human resource 
disclosure (Akintoye, 2012; Hossain, Khan, \& Haque, 2018).

To this end, Cooke (1991) and Ahmed and Nichollas (1994) showed a significant relationship between firm size and voluntary disclosure. Ismail (2002), Silva and Christensen (2004), Spiegel and Yamori (2004) and Hossain (2010) exhibited a positive relationship between size and the level of human resource disclosure, while McNally, Lee and Haseldine (1982) concluded that size is an important characteristic in establishing the leaders in voluntary disclosure practice. However, no relationship was found between firm size and human resource accounting disclosure by prior studies such as Athanasios et al., (2013), Ullah and Karim (2015) and Sarkar et al., (2016). As a result, firm size is being considered as a determinant of human resource accounting disclosure. Hence, the following hypothesis is examined:

$\mathrm{H}_{2}$ : There is no significant relationship between firm size and the extent of human resource accounting disclosure by the banking industry in Nigeria.

\subsubsection{Listing Age and Human Resource Accounting Disclosure}

Listing age is an important factor to evaluate human resource accounting disclosure. Athanasios et al., (2013) elaborates reason why company's human resource information disclosure can be affected by its listing age. The reasons for these are: immature companies can suffer competitive disadvantage; collection and reporting of information can be costly and difficult for immature companies; and there may not be comprehensive information for the younger companies. Therefore, listing age is the length of time a company has been listed on a stock market. Thus, listing age was measured by the number of years since listed on the Nigeria Stock Exchange.

Empirically, Sarkar et al. (2016) showed a positive association between listing age and human resource disclosure in Bangladesh banking sector. However, Athanasios et al. (2013) and Ullah and Karim (2015) exhibited no relationship in the annual reports of banking sector of Greek and Bangladesh using regression analysis. Therefore, these results suggest the following hypothesis:

$\mathrm{H}_{3}$ : There is no significant relationship between listing age and the extent of human resource accounting disclosure of the banking industry in Nigeria.

\section{Methodology}

This study adopted the use of the secondary method of data collection from annual reports and corporate website of listed banks in Nigeria. This is as a result of the fact that annual reports are audited, mostly consistent, reliable and regular medium to communicate with stakeholders (Ullah \& Karim, 2015; Sarkar et al., 2016; Jinadu et al., 2018). The population consisted of 16 banks quoted on the Nigeria Stock Exchange as at $31^{\text {st }}$ December 2018. These banks were considered appropriate for this very study because they are by law required to annually submit their published financial statements to the Securities and Exchange Commission (SEC).

To achieve this purpose, a human resource accounting disclosure index (HRADI) was used to 
measure human resource accounting. The disclosure index was utilised for the quoted banks based on 22 disclosure checklist items (Appendix 1). To measure the disclosure level, an un-weighted disclosure index approach was used. This approach is most appropriate when all human resource accounting disclosure items are regarded as equally important to every user and assigned equal weighting (Sarkar et al., 2016).

In addition, the items of human resource accounting information were scored numerically on a dichotomous procedure. According to un-weighted disclosure approach, a company is scored (1) for an item disclosed in the annual report and (0) if not disclosed. The total voluntary disclosure index was then calculated for each bank as a proportion of the total disclosure score to the maximum number of items reported. This method was adopted because it was not biased to a specific user (Barako, 2007). However, prior studies using weighted disclosure index have been found to be biased between different levels of disclosure and regards information items to be more important than the other (Barako, 2007), while the unweighted disclosure index was found to ensure that all disclosure items are equally essential (Sarkar et al., 2016; Aggarwal \& Verma, 2020). Thus, the disclosure index for each bank is then expressed as a percentage. The disclosure index, according to Sarkar et al., 2016 can be mathematically shown as follows:

$$
\text { HRADI }=\frac{\text { HRADS of individual bank }}{\text { Maximum possible score obtainable }} \times 100
$$

\subsection{Model Specification}

For the purpose of measuring the relationship between dependent and independent variables, an econometric model adapted from the study of Ullah and Karim (2015) and Sarkar et al., (2016) is hereby expressed clearly in equations 1 and 2 respectively.

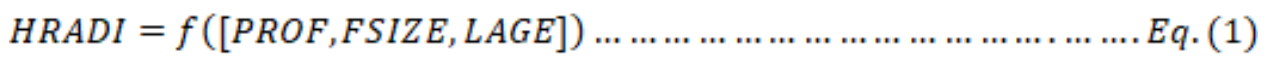

Equation (1) is expressed explicitly as:

$$
H R A D I=\beta_{0 \mathrm{it}}+\beta_{1} \text { PROF }_{\text {it }}+\beta_{2} \text { FSIZE } E_{\text {it }}+\beta_{3} L A G E_{\text {it }}+\mu_{\text {it }}
$$

Where: $H R A D I=$ Human Resource Accounting Disclosure Index

$\beta_{0}=$ Intercept of the regression line, regarded as constant

$\beta_{1-3}=$ Coefficient or slope of the regression line or independent variables

$P R O F=$ Profitability (measured by ratio of profit before interest and taxes to sales).

FSIZE = Firm Size (measured by natural logarithm of total assets).

$L A G E=$ Listing Age (measured by the number of years since listed on Nigeria Stock Exchange).

$\mu=$ Error term that represents additional independent variables that affect the model but not captured. ' $t$ ' $=$ year or period and $i=$ bank. 


\section{Discussion of Findings}

The descriptive statistics as shown in Table (4.1) for the sample banks indicate that the total human resource accounting disclosure represents $16.7 \%$ of the maximum human resource disclosure checklist items. This result is very low like the study by Bowrin (2018). As a result, it is characterised by self-constructed disclosure index, lack of awareness and lack of mandatory regulation.

Moreover, skewness and kurtosis reveal that all the variables are normally distributed at 5\% level of significance. In addition, the skewness and kurtosis statistics of the variables are within the normally distributed range of \pm 1.96 and \pm 3 . (Haniffa \& Hudaib, 2006). Thus, the variables suggest normality. In addition, the data demonstrated a high consistency as the mean and median are within the minimum and maximum scores.

Furthermore, Table (4.2) presents a correlation coefficient(r) result among the variables. A significant relationship is identified at a confidence level of $95 \%$. Results indicate that at this level of human resource accounting disclosure, there is a significant positive relationship between human resource accounting disclosure and its determinants. The Pearson correlation matrix shows that the correlation coefficients are less than 0.8 , the limit correlation percentage commonly suggested by prior studies after which multicollinearity is likely to exist (Hossain, Islam \& Andrew, 2006).

Similarly, the result of variance inflation factor (VIF) further tests the presence of multicollinearity. Accordingly, Gujarati (2003) found no problem about multicollinearity provided the VIF of the independent variables are less than 10 and the tolerance coefficients greater than 0.10. Table (4.3) displays the highest VIF as 1.35 and the least tolerance coefficient was 0.740 . Hence, the results of VIF and tolerance coefficients show an acceptable level of multicollinearity among the variables. These findings suggest that there is no problem about correlation.

Table 4.1. Result of Descriptive statistics of the Variables

\begin{tabular}{|l|c|c|c|c|}
\hline & HRADI & PROF & FSIZE & LAGE \\
\hline Mean & 16.71250 & 0.117125 & 1771119. & 15.50000 \\
\hline Median & 17.00000 & 0.120000 & 1338678. & 11.00000 \\
\hline Maximum & 19.00000 & 0.580000 & 5595253. & 47.00000 \\
\hline Minimum & 11.00000 & -0.640000 & 12240.00 & 0.000000 \\
\hline Std. Dev. & 1.494240 & 0.210275 & 1363537. & 12.89196 \\
\hline Skewness & -0.698904 & -0.788656 & 0.961920 & 1.252451 \\
\hline Kurtosis & 2.327513 & 2.660004 & 2.902795 & 3.013092 \\
\hline Jarque-Bera & 87.31652 & 31.87844 & 12.37242 & 22.12753 \\
\hline Probability & 0.000000 & 0.000000 & 0.002058 & 0.000016 \\
\hline Sum & 1337.000 & 9.370000 & $1.42 \mathrm{E}+08$ & 1240.000 \\
\hline Sum Sq. Dev. & 176.3875 & 3.493039 & $1.47 \mathrm{E}+14$ & 13130.00 \\
\hline Observations & 80 & 80 & 80 & 80 \\
\hline
\end{tabular}


Source: Authors' computation from E-view 9.5

Table 4.2. Correlation matrix between the variables

\begin{tabular}{|l|c|c|c|c|}
\hline & HRADI & PROF & FSIZE & LAGE \\
\hline HRADI & 1.000000 & & & \\
\hline PROF & 0.427198 & 1.000000 & & \\
\hline FSIZE & 0.305503 & 0.486344 & 1.000000 & \\
\hline LAGE & 0.070639 & 0.179657 & 0.053304 & 1.000000 \\
\hline
\end{tabular}

Source: Authors' computation from E-view 9.5

Table 4.3. Variance Inflation Factor (VIF)

\begin{tabular}{|l|c|c|}
\hline \multicolumn{1}{|c|}{ Variable } & VIF & Tolerance 1/VIF \\
\hline Profitability & 1.35 & 0.740 \\
\hline Firm Size & 1.31 & 0.762 \\
\hline Listing Age & 1.03 & 0.966 \\
\hline Mean VIF & \multicolumn{2}{|c|}{1.23} \\
\hline
\end{tabular}

Source: Authors' computation from E-view 9.5

Table 4.4. Panel Least Square Regression Result for the Hypotheses

\begin{tabular}{lrlll}
\hline \hline \multicolumn{1}{c}{ Variable } & Coefficient & Std. Error & t-Statistic & Prob. \\
\hline \hline C & 16.16340 & 0.309339 & 52.25146 & 0.0000 \\
PROF & 2.595874 & 0.850299 & 3.052894 & 0.0031 \\
FSIZE & $1.40 \mathrm{E}-07$ & $1.29 \mathrm{E}-07$ & 1.085334 & 0.0212 \\
LAGE & -0.000210 & 0.012135 & -0.017287 & 0.9863 \\
\hline \hline R-squared & 0.795013 & Mean dependent var & 16.71250 \\
Adjusted R-squared & 0.763238 & S.D. dependent var & 1.494240 \\
S.E. of regression & 1.366852 & Akaike info criterion 3.511604 \\
Sum squared resid & 141.9896 & Schwarz criterion & 3.630706 \\
Log likelihood & -136.4642 & Hannan-Quinn criter.3.559355 \\
F-statistic & 6.137166 & Durbin-Watson stat & 2.134159 \\
Prob(F-statistic) & 0.000857 & & & \\
\hline \hline
\end{tabular}

Source: Author's computation from E-View 9.5

Table (4.4) shows the results of the regression model used for the three hypotheses. A review of the regression analysis results on hypothesis one $\left(\mathrm{H}_{1}\right)$ shows that there is a significant positive relationship between profitability and human resource accounting disclosure. The findings show that the P-value (0.003) and T-statistic (3.053) is lower than the 5\% significant level. Hence, the null hypothesis $\left(\mathrm{H}_{1}\right)$ is rejected and alternate hypothesis accepted. This implies that banks' profitability enhances the disclosure of human resource accounting 
information to various stakeholders. This result is consistent with the studies by Micah et al. (2012), Akintoye (2012), Enofe et al. (2013) and Aggarwal and Verma (2020) that showed a significant relationship between profitability and human resource accounting disclosure. Nevertheless, the results of the studies by Athanasios et al., (2013), Ullah and Karim (2015) and Sarkar et al., (2016) revealed no relationship.

Similarly, firm size reveals a significant positive relationship with the extent of human resource accounting disclosure. The results reveal that the P-value (0.021) and T-statistic (1.085) is lesser than 5\% significant level. Hence, the null hypothesis $\left(\mathrm{H}_{2}\right)$ is rejected and alternate hypothesis accepted. This indicates that banks with larger firm size encourage management to disseminate more human resource information. This result is in conformity with the studies by Silva and Christensen (2004), Spiegel and Yamori (2004) and Hossain (2010) that showed a positive relationship between firm size and human resource accounting disclosure. However, the study contradicts the work of Athanasios et al., (2013), Ullah and Karim (2015) and Sarkar et al., (2016) where an insignificant negative relationship was found.

However, findings from the third hypothesis show that listing age displays an insignificant negative relationship with the extent of human resource accounting disclosure. This is evident in the p-values (0.986) and T-statistic (-1.017) of the Panel regression technique that were above 5\% significant level. Therefore, the result supported the acceptance of null hypothesis $\left(\mathrm{H}_{03}\right)$ contrary to the alternate hypothesis with respect to listing age. This suggests that a reduction in the duration a firm is listed on the Stock Exchange is associated with lower level of human resource accounting disclosure. The finding is in conformance to the existing research results of Athansioos et al., (2013) and Ullah and Karim (2015) where an insignificant relationship between listing age and human resource accounting disclosure was found. However, a significant relationship between listing age and human resource accounting disclosure existed in the study by Sarkar et al., (2016) of listed companies in Bangladesh.

\section{Conclusion and Recommendation}

This study basically examines the relationship between corporate determinants and human resource accounting disclosure in annual reports and corporate website of listed banks in Nigeria. It also looks at whether human resource accounting disclosure is influenced by profitability, firm size and listing age. The study uses three hypotheses in testing human resource accounting disclosure and its determinants. The results from our test reveal a significant positive relationship between profitability, firm size and human resource accounting disclosure. In addition, listing age exhibits no significant association with the level of human resource accounting disclosure. Hence, the study concludes that compliance with international best practices on human resource accounting disclosure will strengthen profitability, firm size and listing age and result in more adequate information disclosure to the needs of stakeholders, thereby reducing reporting-gap.

On the basis of the foregoing, the study hereby recommends that listed banks in Nigeria are to be encouraged to mandatorily disclose human resource accounting information so as to 
enhance their social reputation and reduce the potential agency costs. However, this study does have its own limitations and, therefore, the conclusions need to be interpreted with caution, as it would serve as an opportunity for further examination in this area of research. As a result, this research is limited to a period of observation of five years data from the Nigeria Stock Exchange. Also, the study only captured listed banks, leaving unlisted banks in the Nigerian economy. In addition, only three determinants are covered in this study. Hence, future study can investigate other variables that are not included in the study such as stakeholder power, growth opportunity and liquidity.

\section{References}

Abhayawansa, S. (2008). An explanation of human capital disclosure from the resource based perspective. Journal of Human Resource Costing and Accounting, 12(1), 51-64. https://doi.org/10.1108/14013380810872752

Adeyemi, S. B., \& Ayanlola, O. S. (2015). Regulatory perspectives for deepening CSR disclosure practice in Nigeria. African Journal of Business Management, 9(6), 270-287. https://doi.org/10.5897/AJBM2014.7499

Adnan, S. M., Staden, C. V., \& Hay, D. (2010). Do culture and governance structure influence CSR reporting quality?: Evidence from China, India, Malaysia and the United kingdom. 6th Asia Pacific Interdisciplinary Research in Accounting Conference (APIRA), 11/07/2010 to 13/07/2010, Sydney, Australia. Available at https://www.researchspace.auckland.ac.nz/docs/uoa-docs/rights.htm

Aggarwal, K., \& Verma, A. (2020). Effect of company characteristics on human resource disclosure index: Empirical evidences from Indian corporates. Management and Labour Studies, 45(1), 85-117. https://doi.org/10.1177/0258042X19890246

Ahangar, R. G. (2011). The relationship between intellectual capital and financial performance: An empirical investigation in an Iranian company. African Journal of Business Management, 5(1), 88-95.

Ahmed, K., \& Nicholls, D. (1994). The impact of non-financial company characteristics on mandatory compliance in developing countries. The case of Bangladash. The International Journal of Accounting, 29(1), 60-77. https://doi.org/10.1080/10293574.1994.10510464

Akbas, H. E. (2014). Company characteristics and environmental disclosure: An empirical investigation on companies listed on Borsa Istanbul. The Journal of Accounting and Finance, $6(2), 145-164$.

Akintoye, I. R. (2012). The relevance of human resource accounting to effective financial reporting. International Journal of Business Management and Economic Review, 3(4), 566-572.

American Accounting Association (1973). Report of the committee on accounting for human resource. The Accounting Review, (48), 169-185.

Athanasios, V., Antonious, S., \& Despma, G. (2013). Company characteristics and human 
resource disclosure in Greece. 6th International Conference on Information and Communication Technologies in Agriculture, Food and Environment (HAICTA 2013), 8(13), 112-121. https://doi.org/10.1016/j.protcy.2013.11.016

Barako, D. G. (2007). Determinants of voluntary disclosures in Kenyan companies annual reports. African Journal of Business Management, 1(5), 113-128.

Bowrin, A. R. (2018). Human resources disclosures by African and Caribbean companies. Journal of Accounting in Emerging Economies, 8(2), 244-278. https://doi.org/10.1108/JAEE-07-2016-0065

Campbell, D., Craven, B., \& Shrives, P. (2003). Voluntary social reporting in three FTSE sectors: A comment on perception and legitimacy. Accounting, Auditing and Accountability Journal, 16(4), 558-581. https://doi.org/10.1108/09513570310492308

Cooke, T. E. (1991). An assessment of voluntary disclosure in the annual reports of Japaness corporation. The International Journal of Accounting, 26(3), 174-189.

Cormier, D., Ledoux, M., \& Magnan, M. (2011). The informational contribution of social and environmental disclosures for investors. Management Decision, 49(8), 1276-1304. https://doi.org/10.1108/00251741111163124

Deegan, C. (2007). Australian financial accounting (5th ed.). Sydney: McGraw-Hill.

Enofe, A. O., Mgbame, C., Otuya, S., \& Ovie, C. (2013). Human resource accounting disclosure in Nigeria quoted firms. Research Journal of Finance and Accounting, 4(13), ISSN 2222-1697 9(Paper) ISSN-2847(Online).

Evangelinos, K. I., \& Skouloudis, A. (2014). European perspectives on corporate nonfinancial disclosure: Evidence from the Southeast. International Journal of Disclosure and Governance, 11, 33-53. https://doi.org/10.1057/jdg.2012.13

Flamholtz, E. (1973). Human resource accounting: Advances in concepts, methods, and applications. Springer.

Gujarati, D. N. (2003). Basic Econometrics (4th edition), London: McGraw-Hill.

Haniffa, R., \& Hudaib, M. (2006). Corporate governance structure and performance of Malaysian listed companies. Journal of Business Finance and Accounting, 33(7/8), 1034-1062. https://doi.org/10.1111/j.1468-5957.2006.00594.x

Harward, P., \& Uptom, O. (2012). Human resource accounting: A new paradigm in the era of globalization. Asian Journal of Management Research, 1(1), 237-244.

Hossain, D. M. (2012). The nature of voluntary disclosures on human resource in the annual reports of Bangladeshi companies. Dhaka University Journal of Business Studies, 25(1).

Hossain, M. A. (2010). Disclosure of financial information in developing countries: A comparative study of non-financial companies in India, Pakistan and Bangladesh. Unpublished PhD Dissertation, The University of Manchester. 


\section{MInstitute Macrink $_{\text {Insthe }}$}

International Journal of Human Resource Studies

ISSN 2162-3058

2020, Vol. 10, No. 4

Hossain, M., Islam, K. \& Andrew, J. (2006). Corporate social and environmental disclosure in developing countries: Evidence from Bangladesh. Proceedings of the Asian Pacific Conference on International Accounting Issues, Hawaii, 1-22. Available at http://www. ro.uow.edu.au/commpapers/179.

Hossain, S. K., Khan, M. R., \& Haque, M. M. (2018). Corporate voluntary disclosure practices and its association with corporate attributes: An empirical investigation of listed and non-listed commercial banks in Bangladesh. International Journal of Managerial and Financial Accounting, 10(4), 331-351. https://doi.org/10.1504/IJMFA.2018.095972

Ismail, T. H. (2002). An empirical investigation of factors influencing voluntary disclosure of financial information on the internet in the GCC countries, Working Paper Series, Social Sciences Research Network. https://doi.org/10.2139/ssrn.420700

Jinadu, O., Uwuigbe, U., Uwuigbe, O. R., Asiriuwa, O., Eriabie, S., Opeyemi, A \& Osiregbemhe, I. S. (2018). Ownership structure and corporate performance of multinational banks; Evidence from Nigeria. Academy of Strategic Management Journal, 17(5), 1-11.

John, A. O. (2016). Human capital accounting information and firms' value: An analysis of selected quoted manufacturing companies in Nigeria (2007-2014). International Journal of Economics, Commerce and Management, 4(5), 14-27.

Khadijeh, K. P. (2015). Relationship between the average disclosure of human resource accounting information and firm value. Research Journal of Recent Sciences, 4(7), 50-54.

Mathews, R. (2004). Developing a matrix approach to categorise the social and environmental accounting research literature. Qualitative Research in Accounting \& Management, 1(1), 30-45. https://doi.org/10.1108/11766090410816280

McNally, M. G., Lec, H. E., \& Haseldine, C. R. (1982). Corporate financial reporting in New Zealand. An analysis of users preferences, corporate characteristics and disclosure practices for discretionary information. Accounting and Business Research, Winter, 11-20. https://doi.org/10.1080/00014788.1982.9729725

Micah, L. C., Ofurum, C. O., \& Ihendinihu, J. U. (2012). Firms financial performance and human resource accounting disclosure in Nigeria. International Journal of Business and Management, 7(14), 67-75. https://doi.org/10.5539/ijbm.v7n14p67

Oba, V. C., \& Fodio, M. I. (2012). Board characteristics and quality of environmental reporting in Nigeria. Journal of Accounting and Management, 2(2), 33-48.

Ojokuku, R. M., \& Oladejo, K. S. (2017). Firm's characteristics and human resource accounting disclosure in Nigerian quoted manufacturing companies. International Journal of Finance and Management, 5(1), 10-22.

Oyewo, B. M. (2013). Comparative analysis of human resource accounting disclosure in Nigeria financial services and manufacturing companies. IOSR Journal of Industrial Relation, $15,55-69$. 


\section{Ml Macrothink}

International Journal of Human Resource Studies ISSN 2162-3058 2020, Vol. 10, No. 4

Rehman, W. U., Rehman, C. A., Rehuman, H. U., \& Zaliad, A. (2011). Intellectual capital performance and its, implication on corporate performance: An empirical evidence form Modaraba sector of Pakistan. Australian Journal of Business and Management Research, 1(5), 8-16.

Sarkar, S. H., Alam, A., \& Ali, I. (2016). Human resource accounting disclosure practices in Bangladesh. Australian Journal of Accounting Economics and Finance, 2(2), 100-113.

Silva, W. M., \& Christensen, T. E. (2004). Determinants of voluntary disclosure of financial information on the internet by Brazilian firms, doi: papers. ssrn.com/so13/papers.cfm? abstract id $=638082$.

Spiegel, M. M., \& Yamori, N. (2004). Determinants of voluntary bank disclosure: Evidence from Japanese Shinkin Banks, CES Ifo Working Paper No s1135: Monetary Policy and International Finance.

Syed, A. M. (2009). Human resource accounting disclosure of Bangladeshi companies and its association with corporate characteristics. BRAC University Journal, 1(1), 35-43.

Ullah, H., \& Karim, T. (2015). Human resource disclosure in annual report of listed banking companies in Bangladesh. Global Journal of Quantitative Science, 2(1), 7-19.

Unerman, J. (2000). Methodological issues: Reflections on quantification in corporate social reporting content analysis. Accounting, Auditing and Accountability Journal, 13(5), 667-680. https://doi.org/10.1108/09513570010353756

\section{Appendix 1}

\section{Human Resource Accounting Disclosure Check List Items.}

\begin{tabular}{|l|l|}
\hline Number & Disclosure items \\
\hline 01 & Separate HRA statement \\
\hline 02 & Total value of human resource \\
\hline 03 & Number of employees \\
\hline 04 & Human resource policy \\
\hline 05 & Training and development \\
\hline 06 & Management succession plan \\
\hline 07 & Employment report \\
\hline 08 & Employee value added in value added statement \\
\hline 09 & Human resource development fund \\
\hline 10 & Employees/workers fund \\
\hline 11 & Retirement benefits policy \\
\hline 12 & Performance recognition \\
\hline 13 & Superannuation fund \\
\hline 14 & Other employees' benefits \\
\hline 15 & Health, safety and environment at work \\
\hline 16 & Employee involvement \\
\hline
\end{tabular}




\begin{tabular}{|l|l|}
\hline 17 & Directors' profile \\
\hline 18 & Number of persons employed, detailed per division/department \\
\hline 19 & Human rights and labor practices disclosure \\
\hline 20 & Remuneration policy for directors and employees \\
\hline 21 & Employees benevolent fund \\
\hline 22 & Employees group insurance \\
\hline
\end{tabular}

Source: Sarkar, Alam and Ali (2016)

\section{Copyright Disclaimer}

Copyright for this article is retained by the author(s), with first publication rights granted to the journal.

This is an open-access article distributed under the terms and conditions of the Creative Commons Attribution license (http://creativecommons.org/licenses/by/4.0/). 